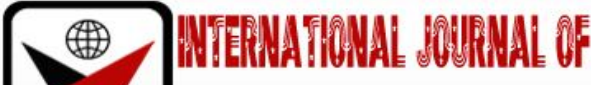

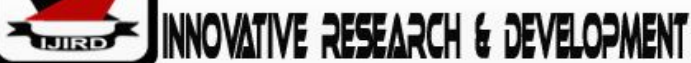

ISSN 2278 - 0211 (Online)

\section{Review on Integrated Management of Fusariumwilt Disease of Cotton}

\author{
Abdurahman Baba Saje \\ Lecturer, Department of Agricultural Technology \\ Yobe State College of Agriculture Gujba, Damaturu, Nigeria
}

\section{Abstract:}

Fusarium wilt disease of cotton is one of the highly destructive disease of cotton plant and is very difficult to manage. No effective control measure for $\mathrm{F}$. wilt of cotton has been found other than resistant cultivars. However, there are no available immune cultivars.

Chemical management of F. wilt of cotton is limited and expensive, and rotation is not effective because of the ability of disease to survive for long period in soil even without the host plant. Since wilt is associated with root-knot nematode, resistance cultivars, chemical, soil amendment and rotation practices directed at management of the nematode have proven in some to be effective in reducing the incidence and severity of $\mathrm{F}$. wilt disease of cotton.

Cultural and biological approaches are considered best because there are environmentally friendly and to health of both human and natural enemies. However, chemical approach is known to easiest but dangerous to health and is consider as a last alternative to control F. wilt disease of cotton.

Keyword: Integrated disease management, Fusariumwilt disease, cotton

\section{Introduction}

Diseases of plant are very significant biotic constraint that leads to crop losses worldwide. Plant diseases mostly caused by bacteria, fungi, phytoplasmas, virus, and nematodes are group of biotic problems that cause serious crop yield losses. Recent study shows that about 10-15\% of crop yield losses are due to disease (Maloy, 2005).

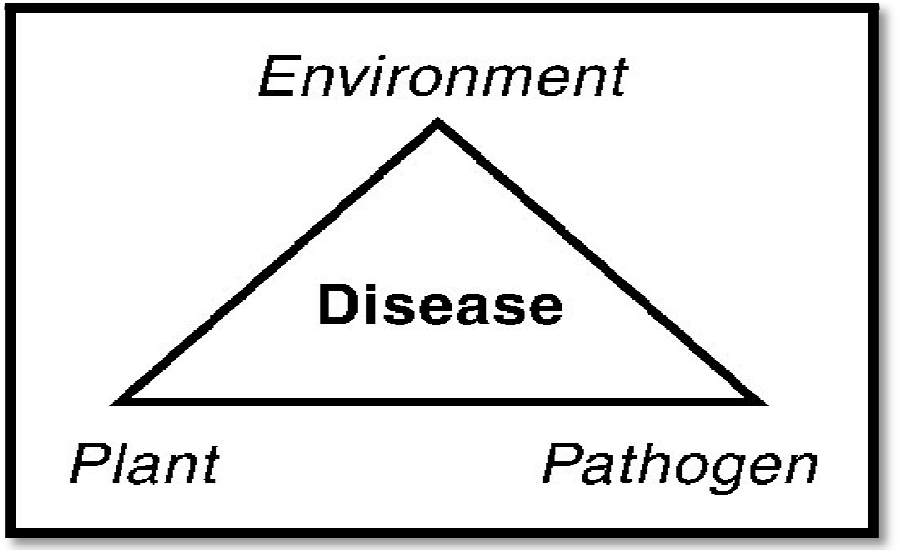

Figure1: Showing Disease Triangle

Source: Google search (2014)

Disease occurs, as a result, of the interaction between three major factors; environment, plant and pathogen. Among the three factors if any is unfavour able disease infestation will not occur. Integrated disease management is based on any factor that can cause unfavour able condition between the factors.

Integrated disease management (IDM) can be defined as a disease control strategy that uses all available management strategies to maintain disease from reaching an economic threshold. It does not encourage the use chemical to prevent disease. However, it serves as means of integration of cultural, biological and sometimes chemical control strategy. The adaptation of IDM strategy is a pre-requisite to sustainable agriculture (E

Cotton belongs to the genus (Gossypium) which usually consist of at least 45 diploid and five allotetraploid species (Ulloa, et al., 2006) as well known to be one of the oldest plant fibres cultivated around the word, and it has been used not only with the aim of producing natural raw materials, but also using its product for the purpose of edible oil, animal feed, 
pharmaceutical uses as well as source of income (chitarra, 2008). The aim of this essay is to critically review the integrated management of Fusarium wilt disease of cotton.

\subsection{Fusarium Wilt of Cotton}

Fusarium wilt of cotton was first described in United States (1892) by Atkinson. About eight genotypes of Fusarium oxysporum f.sp vasinfectum (fov), called races have describe and known throughout the world (DeVay, 1986 and Smith et al., 1981). The races were identified and classified based on their pathogenicity tests on different species of cotton, G. hirsutum, G. barbadense and G. arboretum L. (Armstrong, 1958 and Ibrahim, 1966). Some races are known to acid sandy soils and interact with nematodes while others are prevalent in alkaline and wet clay soils.

Fusarium wilt of cotton caused by Fov is a serious fungal disease of cotton that is responsible for crucial yield and crop losses in all cotton growing area. Fov can survive in soil for several years and cannot be eradicated once found on the field even in the absence of cotton (Hillocks, 1992). The fungus Fusarium oxysporum is very diverse in saprophytic and pathogenic forms. Fov can affect plant at any stage; under conducive environment crop losses will be high when susceptible cultivars are grown on infested field (DeVay et al., 1997). The incidence of disease in seedlings can be high in cold environment, although mean temperature of about $23^{\circ} \mathrm{C}$ favour disease but higher temperatures of above $28^{\circ} \mathrm{C}$ reduces the symptom expression. F. wilt is to resist attack until they were stress by other factors. However, there are great losses due F.wilt of cotton depending on the virulence of Fov, host ability to resistance, environment, as well as interaction with nematodes (Hao, et al., 2009).

\subsection{Disease Life Cycle}

F. wilt can invade the root system or other underground parts of host plants through wounds that are caused while transplanting once is within the plant, chlamydospore multiple and grows in the vascular stem of the root, and it then moves to the upper part in the stream sap by spores and lodge, germinate as well as affect other new part of plant. The toxic substance is secreted during interaction of fungus and host plant. These apparently causes wilting and death of the plant, once introduced in the area it persist even in the absences of cotton plant for over 10 years period (Smith, et al., 2001). The strain of Fov is specifically known to cause wilt disease of cotton that plant at any stage. Below is a representational diagram of $\mathrm{F}$. wilt disease of cotton

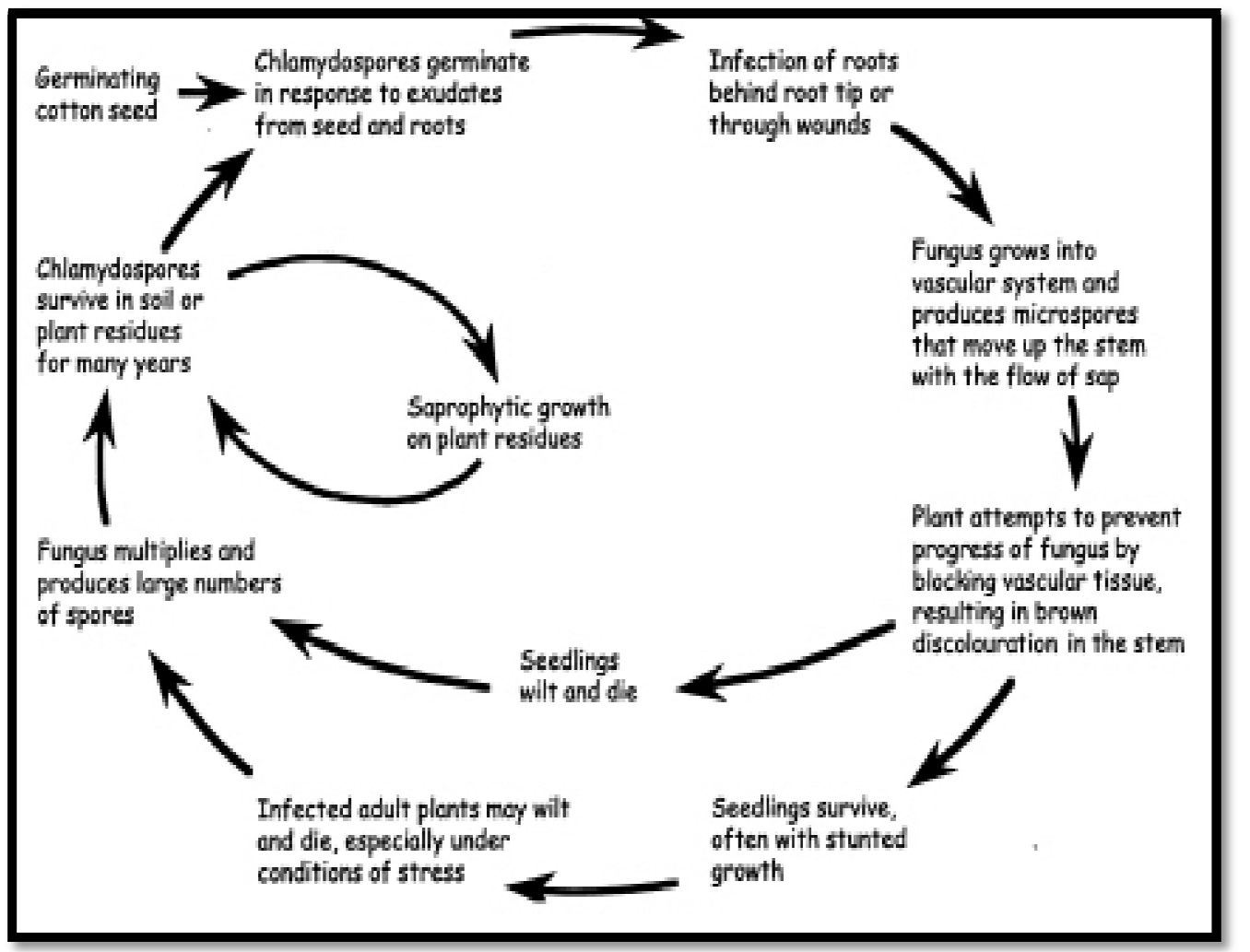

Figure 2: Showing F. Wilt Disease Lifecycle Source: Google Search, 2014

\subsection{Symptoms}

Typical symptoms of F. wilt are based on two symptoms external and internal, and can appear at any stage of crop development. Stunted growth and yellow leaves appear dull before chlorosis and necrosis of the leave margin. Fov have the ability to infect host through taproots behind the root tip. The effect of lipoidal substances produces by the host, and fungal metabolites in combined can cause to occlusion of the vascular tissue (Shi, et al., 1992). Which further lead to brown discoloration (Colyer, 2001). Younger plants tend to die early when symptom develops. Severity of damage depends on; inoculum fungal distribution, the degree of internal vascular discolouration, time of fungal infection as well as weather 
(Hutmacher, et al., 2004). However, the only way F. wilt can be diagnosed is by brown colour appearance inside the stem of affected cotton plan
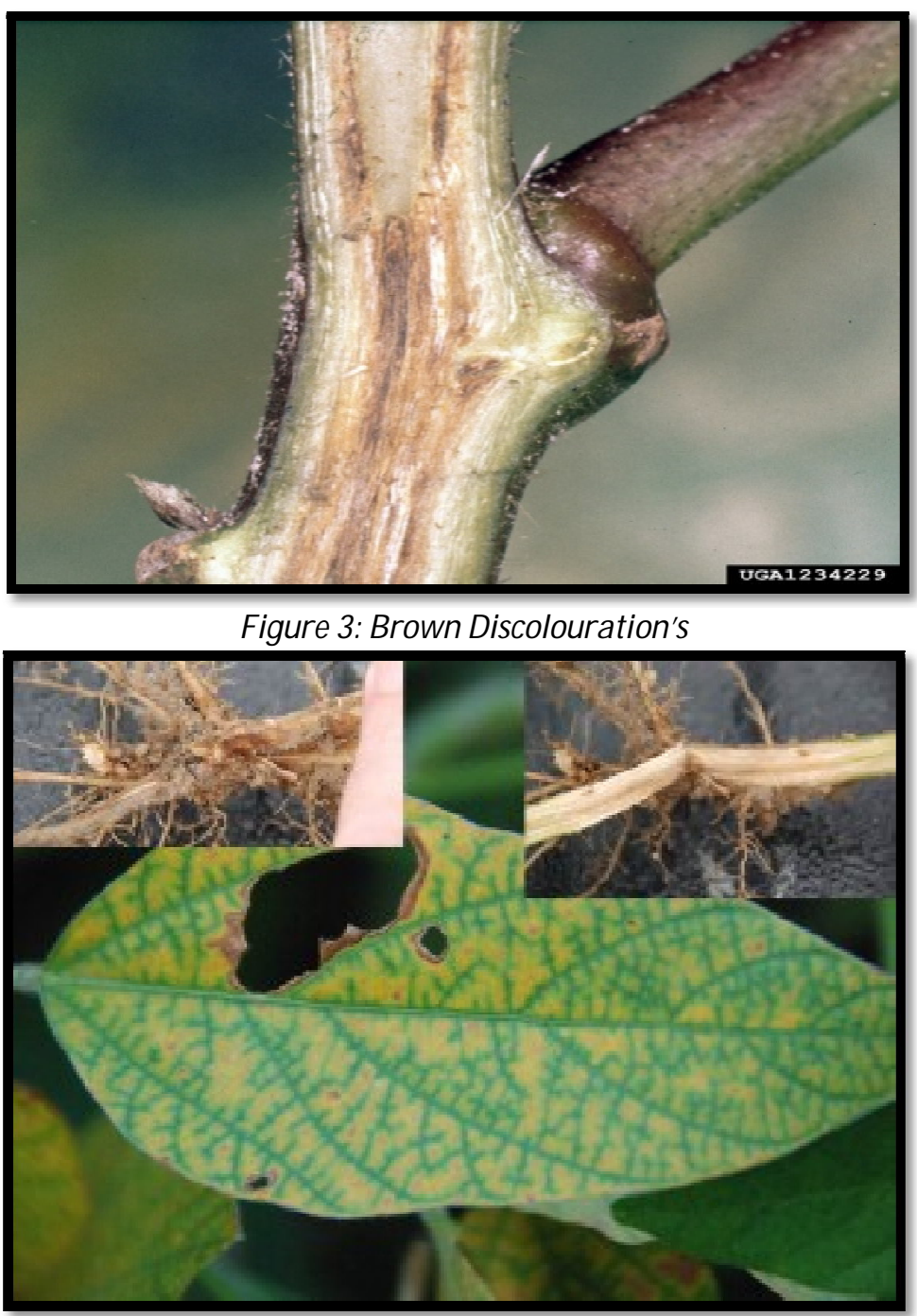

Figure 4: Leaf Chlorosis

Source: Google Search, 2014

\subsection{Key Factors In Fusarium. Wilt Incidence}

There are certain numbers of factors that influence the development of F. wilt in cotton grown areas. These include; presence of the pathogenic strain of the fungus in the infested area, susceptibility of cotton cultivars to the disease, soil type climatic condition and soil borne living microorganisms. The interaction of all these factors leads to the development and affect the amount of wilt in a crop.

- Presence of the pathogenic strain of the fungus in soil: F. wilt has the ability to survive in soil many decades, so this case the pathogenic strain must be presence in the soil without showing any symptoms being present. (Davis, et al., 2006). The presence only becomes evident when there are numerous number of fungal propagules contact with the root in the soil that then causes infection. Once established it can be spread in contaminated soil attached to farm equipment such as boot, knives and vehicles.

- Soil type: in some races there is correlation between the fungus races and the soil type. For example race 1 and 2 were first describe in USA, to occur in sandy soil with approximate PH value of 5-6.5 while 3 and 4 are prevalent in clay soils in Egypt and India (Hillocks, 1992). However, most of them occur in black heavy clays soil and even in lighter soils in some cases.

- Interaction with soil borne living microorganisms: in many cases where interaction occurs between Fov and the microorganisms may increases of suppresses the wilt incidence (Hillocks, 1992). Recently, it has been reported in USA nematodes interacting with race 1 and 2 leads to the increased of wilt incidence in susceptible cultivars (Kochman, 1996).

\subsection{Integrated Disease Management (IDM) Principles}

Plant disease management must be based on sound economic principles strategies to reduce the potential fungal disease infestation in the field. Below are the basic principles:

- Exclusion

- Avoidance 
- Resistance cultivars

- Eradication

- protection

- Exclusion: is a means or method of where by pathogen are prevented from infecting another new field where the disease is not prevalent for example using certified seed, quarantine inspection and inspection of infested material to eradicate inoculum. The basic assumption is pathogen can be transferred from one area to another within short distance with the help of any agent such as; human intervention or other vectors. Exclusion is among the important way of managing disease infestation (Ploetz, 2007).

- Avoidance: is a process whereby disease is prevented from infesting an area by choosing a time of a year calendar or site where there is no pathogen inoculum or the environment of is not conducive for the development of the disease. Example, suitable site, using certified seed that can withstand disease infestation and planting on time

- Resistance cultivars: is the only ideal way to control cotton disease, if satisfactory levels of durable can be utilized and incorporated into culturally crop plant management. Resistance cultivars save time, effort, money as well as reduces the use of chemical for the purpose of managing and controlling disease. Resistance reduces economic losses, yield reduction as well as additional cost of control (Maloy, 1993). Resistant cultivars will certainly reduce or slow the build-up of F. wilt in the soil, compared with susceptible cultivars. However, when weather conditions are favourable to the disease development, incidence may certainly increase even in resistance cultivars (Reid, et al., 2004). Planting cotton resistance cultivars is the most important IDM principles of controlling and managing $F$. wilt of cotton.

- Eradication: is refers to the process of removing or eliminating inoculum in an infested area, after it been introduced before widely spreading or established in the area. It usually involves the destruction of numerously infested plants in the affected area; several disease infestations have been reported to be eradicated after infestation. However, it is not successful. Example by sanitising the disease affecting cotton by soil solarisation, chemical application and crop rotation by non-susceptible cultivars (Maloy and Baudoin, 2001).

- Protection: this principle is basically on setting or establishing a barrier between the (host plants) those that are susceptible and pathogen. The assumption of this principle is based on present of the pathogen and the infection will certainly occur without protective intervention strategy. For example, F. wilt of cotton lives in soil for long period. Protection and prevention it includes particular cultural practice such as; tillage, irrigation and altering soil PH and other practices that reduce the disease severity (Hillocks, 1992).

\subsection{Components of IDM}

In other to achieve the IDM principles, it has to be practice in one of the four component of IDM. Below are IDM components of cotton F. wilt disease

- Cultural control

- Biological control

- Chemical control and

- Resistance cultivars

\subsubsection{Cultural Control}

Cultural control method is IDM methods that modify the environment to suppress the prevalence of the inoculum pathogen. This method has a different range of strategy that includes; planting resistant cultivars, planting date and rotation with non-susceptible crops for example; cotton rotating with corn and soil solarisation to reduce the infestation of pathogen (Wright, et al., 2013). Cultural control is effective control strategy if combine with the other control strategy.

Crop rotation: is the practice of growing a series of different crops in the same land in sequential seasons. It also mitigates the build-up of pathogen and disease that often occurs when one species is continuously cropped. For example, nematodes can build up with repeated tomato crops in the same land. However, F. wilt

Another means of killing different soil-borne pathogenic fungi is by soil amendment of the field with a full spread of organic nitrogen (>3\% w/w) (Lazarovits et al., 2008).

Once F. wilt established chlamydospore in the soil, it is almost very difficult to eradicate because it can survive in the soil for several decades in the absence of cotton rotation limits the effectiveness of Fov (Davis et al., 2006).

Soil amendments were used to reduce the severity of $\mathrm{F}$. wilt disease. Calcium as $\mathrm{CaCO}_{3}$ or $\mathrm{Ca}(\mathrm{OH})$ application to F. wilt conducive soil decreases the germination ability of chlamydospores (Peng et al., 1999). The amount of nitrogen added to soil can also alter the soil PH and the severity of the disease. Nitrogen fertilizer containing nitrate nitrogen $\left(\mathrm{NO}_{3}-\mathrm{N}\right)$ reduces F. wilt compare to fertilizer containing ammonium nitrogen $\left(\mathrm{NH}_{4}-\mathrm{N}\right)$. It has reported that $\mathrm{NH}_{4}-\mathrm{N}$ is needed for germ-tube germination and growth of F. wilt (Ciotola et al., 2000). However, once chlamydospores and nematodes interact is difficult to eradicate because it is cost efficient, labourers and nematode have to manage or control by nematicides and beyond that resistant cultivars to both F. wilt and nematodes. However, resistant cultivars are not complete measure to be taken.

Likely the use of rotation involving non-host pathogen will reduce the rate at which the fungus will builds up in the soil but the most appropriate crop to use may also differ with race of the pathogen and the type of soil in the field. 


\subsubsection{Biological Control}

The use of chemicals has been a major issue of concise on the environment, their inactiveness against soil-borne pathogen such as F. wilt so there is a need to find other alternatives to chemical use against plant disease (Whipps, 2001).

Biological control approach means the use of an organism to suppress the mode of action on another density area of an organism. It is also considered as the IDM, which is a successful method of controlling disease in an environment in a cost effective way. Both man-made and natural biological controls actively participate in the ecosystem. Natural biological control occurs, as a result, of green plant on earth that can produce biomass to sustain another means of life, with the help of biological control the plants produces. Natural biological control is the means of suppressing the number of pathogen naturally in the ecosystem without any human intervention (Kogan, 1998). For example addition of Bacillus subtillis spores to a cotton seed. This treatment reduces the severity of soil-borne pathogens of the cotton (Brannen and Kenney, 1997).

Soil solarisation is a process of heating soil by covering with transparent polythene to trap solar energy to control soil-borne disease during the hot period (Gamliel and Katan, 2009). The main purpose of the treatment is to reduce inoculum population in infested soil and to reduce the need of chemical fumigants. However, the effectiveness of the treatment may be limited to areas where optimal period of solarisation can conflict with planting schedule (Bonnet et al., 2005).

Soil solarisation of infested field of cotton has been proven to be effective (Katan et al., 1983 and Ioannou et al., 1998). Solarisation reduces the incidence of $F$. wilt by $97.5,58$, and $0 \%$ when covered with double layers of polyethylene film, a single piece film layer and uncovered field respectively (Ben-Yephet, et al., 1987). Once the interaction of F. wilt and nematodes occur in the cotton field is very difficult to eradicate. However, the combination of solarisation and methamsodium are known to be very effective in suppressing both F. wilt and nematode than with solarisation or metham-sodium alone (Hillocks, 1992). Most cotton growers are sceptical about using solarisation on the field, because the field need to be free of cultivation for about one month (Minuto et al., 2006). However, in combination with bio-control agent, the period needed to solarise can be reduced (Dong, et al., 2006).

\subsubsection{Chemical Control}

Involves the use of chemical fungicide to control soil pathogen, this particular mode of action often involves under biological or bio-rational control. Chemical methods are only needed where it became necessary or when no effective alternatives are available or are not sufficient to keep pathogen population from reaching damaging levels as the last resort in controlling pest.

F. wilt infestation can be decreased by fumigating soil with methyl bromide (Hillocks, 1992). For example, a mixture of chloropicirin and methyl bromide, although this type of treatment is usually limited to very high value crop plant that are grown on a small field not crop planted over a large field (Hillocks, 1992). In cotton field where wilt infestation is associated with root-knot nematodes, the incidence of the disease can be suppressed with 1,3dichloropropene and metam sodium (Hillocks and Kibani, 2002).

Aldicard can reduce nematode populations and root galls (Koening, et al., 2004). However, less information and knowledge on its effect on F. wilt. The effects of aldicard (Temik 15G) on disease severity of eight different cotton cultivars with different resistibility were tested in 1994 and 1995 (Colyer, et al., 1997). In all the cultivars, application of aldicard suppresses the stem discoloration and root galling. These differences leads to cotton seed yield and lint percentage.

\subsubsection{Resistance Cultivars}

Introducing resistance ability of F. wilt to cultivars can be done through conventional and unconventional breeding. By conventional breeding; in this process resistance is introduced from the parent plants to offspring when any of the parents contributes desire trait such as; short life cycle and the nutrition yield by sexual recombination (Hwang, 1999). Using conventional breeding, resistance ability cotton has been developed against F. wilt (Ulloa et al., 2006).

Using resistance cultivars to manage F. wilt has been successful in Egypt, Tanzania and China (Hillocks, 1992). Because nematodes may increase the disease incidence in both resistance and susceptible to F. wilt (Reid, et al., 2004). Planting cotton resistance cultivars is a good management practice. High level of resistance cultivars to M. incognita suppresses the F. wilt severity more rapidly than tolerance to wilt or moderate resistance to nematodes (Abd-Elsalam et al., 2009).

\section{Conclusion}

F. wilt disease of cotton is one of the highly destructive disease of cotton plant and is very difficult to manage. No effective control measure for F. wilt of cotton has been found other than resistant cultivars. However, there are no available immune cultivars.

Chemical management of cotton F. wilt is limited and expensive, and rotation is not effective because of the ability of disease to survive for long period in soil. Since wilt is associated with root-knot nematode, resistance cultivars, chemical, soil amendment and rotation practices directed at management of the nematode have proven in some literatures to be effective in reducing the incidence and severity of $F$. wilt disease of cotton.

Cultural and biological approaches are considered best because there are environmentally friendly and to health of both human and natural enemies. However, chemical approach is known to easiest but dangerous to health and is consider as a last alternative to control F. wilt disease of cotton. 


\section{References}

i. Abdl-Elsalam, K.A., Omar, M.R., Migheli, Q., Nirenberg, H.I. (2009). Genetic characterization of Fusarium oxysporum f. sp. Vasinfectum isolates by random amplification of polymorphic DNA (RAPD) and amplified fragment length polymorphism (AFLP). Journal of plant disease and protection. 111, 534-544.

ii. Ben-Yephet, Y., Stapleton, J.J., Wakeman, R.J., DeVay, J.E. (1987). Comparative effects of soil solarisation with single and double layers of polyethylene film on survival of Fusarium oxysporum f. sp. Vasinfectum. Phytoparasitica. 15, 181-185.

iii. Bonnet-Suarez, E., Lopez-Herrera, C.J., Melero-Vara, J.M., Prados-Ligero, A.M. (2005). Thermal inactivation of Fusarium oxysporum f. sp. Dianthi and its eradication by soil solarisation at different depths. Acta Hortic. 698, 161-165.

iv. Chitarra, L.G. (2008). Identificacao e controle das principais doencas do algodoeiro. Cartilha tecnica. Embrapa algodao. Campina grande. 2, (2), 65.

v. Colyer, P.D. (2001). Fusarium wilt. In: compendium of cotton disease 2nd ed. Kirkpatrick, T.L. and Rothrock, C.S. APS press. Pp. 27-28.

vi. Colyer, P.D., Kirkpatrick, T.L., Caldwell, W. D., Vernon, P.R. (1997). Influence of nematicide application on the severity of root-knot nematode Fusarium wilt disease complex in cotton. Plant dis. 81, 66-70.

vii. Ciotola, M., DiTommaso, A., Watson, A.K. (2000). Chlamydospore production inoculation methods and pathogenicity Fusarium oxysporum M12-4A. A biocontrol for Striga hermonthica. Biocontrol science and technology. 10, 129-145.

viii. Davis, R.M., Colyer, P.D., Rothrock, C.S., Kochman, J.K. (2006). Plant disease. Fusarium wilt of cotton: population diversity and implications for management. The American phytopathological society. 90, 699-610.

ix. DeVay, J.E. (1986). Half a century dynamics and control of cotton disease: Fusarium and Verticillium wilts. In: proc. Beltwide cotton prod. Res. Conf. natl. cotton counc. Am., Memphis, TN. PP. 35-41.

x. DeVay, J.E., Gutierrez, A.P., Pullman, G.S., Wakeman, R.H., Garber, D.P., Jeffers, S.N., Smith, S.N., Goodell, P.B., Robert, P.A. (1997). Inoculum densities of Fusarium oxysporum f. sp. Vasinfectum and Meloidogyne incognita in relation to development of Fusarium wilt and the phenology of cotton plants (Gossypium hirsutum). Phytopathol. 87, 341346.

xi. Dong, H., Zhang, X., Choen, Y., Zhou, Y., Li, W., Li, Z. (2006). Dry mycelium of Penicillium chrysogenum protects cotton plants against wilt disease and increases yield under field conditions. Plant protection. 25, 324-330.

xii. Gamliel, A., and Katan, J. (2009). Control of plant disease through soil solarisation. In: walters, D. (ed). Disease control in crops. Blackwell publishing ltd. Edinburgh. Pp. 196-220.

xiii. Hao, J.J., Yang, M.E., Davis, R.M. (2009). Effect of soil inoculum density of Fusarium oxysporum f. sp. Vasinfectum race 4 on disease development in cotton. Plant dis. 93, 1324-1328.

xiv. Hillocks, R. J. (1992). Fusarium wilt. Cotton diseases., 127-160.

xv. Hillocks, R.J., and Kibani, T.H.M. (2002). Factors affecting the distribution, incidence and spread of Fusarium wilt of cotton in Tanzania. Expl. Agric. 38, 13-27.

xvi. Hutmacher, B., Micheal, R.D., pete, G., Steve, W., Munk, D., Roberts, B., Marsh, B. (2004). Cotton management guide lines. Fusarium disease cycle and transmission, containment recommendations. Pp 1-2. Accessed on 08/ 06/ 2014. Available at http:/ / cottoninfo.ucdavis.edu/ files/ 134062.pdf

xvii. Ibrahim, F.M. (1966). A new race of the cotton wilt Fusarium in the Sudan Gezira. Empire cotton growing rev. 43, 296-299.

xviii. Koening, S.R, Kirkpatrick, T.L., Starr, J.L., Wrather, J.A., Walker, N.R, Mueller, J.D. (2004). Plant-parasitic nematodes attacking cotton in United States: old and emerging production challenges. Plant dis. 88, 100-113.

xix. Kogan, M. (1998). Integrated pest management. Historical perspectives and contemporary development, Annual review Entomology. 43, 243-247.

xx. lazarovits, G., Conn, K.L., Abassi, P.A., Soltani, N., Kelly, W., McMillan, E., Peters, R.D., Drake, K.A. (2008). Reduction of potato tuber diseases with organic soil amendments in two Prince Edward Island fields. Can. J. Plant pathol. 30, 37-45.

xxi. Maloy, C. O. (2005). Plant disease management. The plant health instructor. Washington state university, Pullman, WA. Pp 20-24.

xxii. Maloy, O.C and Baudoin, A. (2001). Disease control principles. In: plant pathology (ed) Maloy, O.C., Murray, T.D. Wiley, New York.pp 330-332.

xxiii. Maloy, O.C. (1993). Plant disease control. Principle and practice. Wiley, New York. pp.13-149.

xxiv. Minute, A., Spadaro, D., Garibaldi, A., Gullino, M.L. (2006). Control of soil-borne pathogens of tomato using a commercial formulation of Streptomuces griseoviridis and solarisation. Crop protection. 25, 468-475.

xxv. Peng, H.X., Sivasithamparam, K., Turner, D.W. (1999). Chlamydospore germination and Furasium wilt of banana plantlets in suppressive and conducive soils are affected by physical and chemical factors. Soil biology and biochemistry. 31, 1363-1374.

xxvi. Reid, P., Allen, S., Kochman, J., Stiller, W., McNamara, G., Lehane, J., Constable, G. (2004). Sicot F-1: a variety with increased resistance to Fusarium wilt. Proceeding of $12^{\text {th }}$ Australian cotton conference, gold coast. Breeding and technology section. 739-740.

xxvii. Shi, J., Mueller, W.C., Beckman, C.H. (1992). Vessel occlusion and secretory activities of vessel contact cell in resistant or susceptible cotton plants infected with Fusarium oxysporum f. sp. Vasinfectum. Physiol. Mol. Plant pathol. 40, 133-147. 
xxviii. Smith, S.N., Ebbels, D.L., Garger, R.H., Kappelman, A.J. (1981). Fusarium wilt of cotton. In: Toussoun, T.A. and Cook, RJ. Fusarium diseases biology and taxonomy. Pennsylvania State: university press, University Park, PA. PP. 29-38.

xxix. Smith, S.N., DeVay, J.E., Hsieh, W.H., Lee, H.J. (2001). Soil-borne population ofFusarium oxysporum f. sp. Vasinfectum. A cooton wilt fungus in California fields. Mycologia, 93, 737-743.

xxx. Ulloa, M., Hutmacher, R.B., Davis, R.M., Wright, S.D., Percy, R., Marsh, B. (2006). Breeding for Fusarium wilt race 4 resistance in cotton under field and greenhouse conditions. The journal of cotton science. 10, 114-127.

xxxi. Whipps, J.M. (2001). Microbial interactions and biocontrol in the rhizosphere. Journal of experimental botany. 52, 487-511.

xxxii. Wright, D. L., Tillman, B., Marois, J., Ferrell, J. A. and DuFault, N. (2013). Management and cultural practices for peanuts. IFAS Extension. University of Florida. SS-AGR-74. 